\title{
Sustainable Agriculture: Unifying Concepts
}

\author{
Juan Gastó1, Leonardo Vera ${ }^{2}$, Lorena Vieli ${ }^{3}$, and René Montalba ${ }^{3}$ \\ ${ }^{1}$ Departamento de Ciencias Animales. Facultad de Agronomía e Ingeniería Forestal. Pontificia Universidad \\ Católica de Chile. Av. Vicuña Mackenna 4860. Santiago, Chile. \\ ${ }^{2}$ Programa en Ciencias de Recursos Naturales, and ${ }^{3}$ Centro de Ecología Aplicada y Sustentabilidad Agraria, \\ Facultad de Ciencias Agropecuarias y Forestales. Universidad de La Frontera. Av. Francisco Salazar 01145. \\ Temuco, Chile.
}

\begin{abstract}
Gastó, J., L. Vera, L. Vieli, and R. Montalba. 2009. Sustainable Agriculture: Unifying Concepts. Cien. Inv. Agr. 36(1): 5-26. This work is the product of a long process that tried to approximate the principia involved in sustainable agriculture in an attempt to analyze it. We believe that these principia are crucial for the systematic, rigorous, and consistent development of sustainable agriculture. The unifying concepts of agriculture sustainability are classified into seven fundamental principles: (i) there is a hierarchy in decision-making with respect to human actions on the landscape and environment; (ii) human impact on the land should be analyzed from different perspectives (local, global, anthropocentric, and ecocentric); (iii) the carrying capacity in an agrarian context is crucial to ecosystem management and design; (iv) humans arrange nature with little consideration of its own natural organization; (v) land-use planning and design are subordinate to the order determinants that occur in a particular situation; (vi) cultural landscape is a result of humans' actions on the land; and, (vii) the concepts of agriculture and rurality lack a territorial connotation, unlike farm and comarca (a region connected through a common local market). Finally, agriculture sustainability should be addressed from various focal points, with a focus on nature and culture as its main determinants.
\end{abstract}

Key words: Agriculture, cultural landscape, nature, territory, sustainability.

\section{Introduction}

The concept of sustainability was formally defined at the United Nations Conference of Stockholm in 1972 (ONU, 1972), where sustainable development was described as development that satisfies the needs of the present generations without affecting the capacity of future generations to satisfy their own needs. Since then, the

Received 26 December 2007. Accepted 27 May 2008.

'Corresponding author: jgasto@uc.cl literature written on this subject is abundant yet repetitive and confusing.

Agriculture is one of the most relevant human activities that affect nature. Because of its transcendence, sustainability should be incorporated as one of its priority dimensions. As a result, the need arises to define the unifying concepts of sustainability relative to agricultural activities.

The present work is a result of a search process which intends to establish the principias to express agriculture sustainability, which is crucial 
to the systematic, accurate, and coherent development of the subject.

In this article, the unifying concepts are classified into seven fundamental dimensions involving topics related to nature hierarchy: dimensions and actions, sustaining capacity, order and organization, cultural landscape, and territory.

\section{Conservation and sustainability}

Conservation has been defined as the permanence of a thing or phenomena, keeping it alive without damage, loss, decay, or waste. This may include customs and virtues. This concept includes the supervision of nature as a whole and its diverse components such as soils, wild fauna, vegetal cover, rivers, forests, and prairies. Stakeholders, land and nature managers, and several different institutions accomplish these functions (Anonym, 1991).

The concept of conservation became important in the Western world when the British conservators of India arrived to the United States in 1907 and were shocked by the degradation of natural resources. They urged a conceptual change from "the economy of natural resources" to the coined concept of "conservation" of natural resources.

The antithesis of conservation was desertification. This latter concept was initially introduced by Aubreville (1949) and later redefined by Kassas (1970) and Dregne (1978, 1987). It reflects the relation between the combined effect of human activities and the environmental conditions on a certain land generating a progressive depletion of the normal environment leading to considerable degradation due to intervention and management (Glantz and Orvlovsky, 1983). All this contributed to the United Nations Conference on Desertification organized by FAO (Food and Agriculture Organization of the United Nations), UNESCO, and WMO (World Meteorological Organization) (ONU, 1977) where desertification was defined as the intensification or extension of decay, especially in marginal rainfall environments; a process leading to the reduction of productive potential and a subsequent biomass decrease, exploitable land capacity, crop yield and human welfare. The result of this process is what the Romans called agri deserti. This occurs when land-use processes do not consider agricultural practices that allow the conservation of the worthiest components of the ecotope and the biocenosis (Gastó, 1993).

The next stage was the formal and systematic incorporation of humans organized as social, cultural, labor, and political agents, triggering and affecting these two antagonistic processes of conservation and desertification. At the same time, the incorporation of technology and economy to the environment occurred as a whole. The first conference towards the evolution from conservation to sustainability was planned and was formally accomplished in the United Nations Conference of Stockholm in 1972 (ONU, 1972). This conference stated that the environment must not be designed only in a physical or natural sense, but as an interaction between natural and social systems, in addition to the human-built environment and the sociocultural environment. They also mentioned that the most advanced societies are aware of the existence of the planet's ecological limits, and that poverty is the fundamental cause of natural resources decay. This was in conflict with arguments that are fundamental to this deterioration in the ruling neoliberal economic and political model.

The model of unlimited economic growth was first questioned in a study conducted by group of scientist lead by Professor Dennis Meadows at the Massachusetts Institute of Technology (Meadows et al., 1972) on growth limits representing the physical restrictions of the planet in relation to human population, unlimited economic growth, production of foods, industrialization, the non renewable resources, and pollution. This was done in complement with the study "Food Production and Energy Crisis" (Pimentel et al., 1973), as a response to the first energy crisis that was taking place at the time, and with a series of important works, such as Mesarovic and Pestel (1975) and Barney (1982), which were in the process of building so-called "Sustainable Development" (Alonso and Sevilla, 1995). As a result, the World Commission 
for the Environment and Development (The Bruntland Commission; WCED, 1987) formally defined sustainable development in 1987 as that which satisfies the needs of the present generations without compromising the capacity of future generations to satisfy their own needs. This implies that there are population needs as well as environmental limitations to satisfy them. Transformation of the economy and society may generate an increase in productivity and equality of opportunities for all (CMMD, 1987). The United Nations Conference on Environment and Development (ONU, 1992) strengthened and agreed to accomplish the conclusions of the Bruntland Commission. As they stated, "States should cooperate to promote a supportive and open international economic system that would lead to economic growth and sustainable development in all countries". Therefore, a new orientation in international relations is required (Alonso and Sevilla, 1995).

In contrast to natural resource conservation, sustainability incorporates and gives specificity to some of the following dimensions: (a) conservation of functions and ecosystemic productive capacity; (b) conservation of economic benefits production; (c) conservation of the water cycle; (d) soil conservation; (e) conservation and development of biodiversity; (f) conservation and development of the landscape quality; (g) conservation and development of carbon balance; (h) product diversification; (i) satisfaction of human needs; (j) harmonic development with local communities; (k) fair and equitable distribution of benefits among agents and among nations; and finally (1) the rights of native peoples (Lele, 1991; Lawrence, 1997; Altieri, 1999; Altieri and Rojas, 1999; Montalba, 2005).

\section{Hierarchical approach in decision making}

Hierarchical theory is a dialectic expression of the General Theory of Systems (Von Bertallanfy, 1975) which arises, in part, as a movement to a general science of complexity (Bohm and Peat, 1987; Capra, 1996). It has been applied to all organizational levels and work scales. Its basic logical operations are definition, classification, and hierarchialization (Gorski and Tavants,
1968). The emphasis is highly focused on systems observation and its roots are in the works by the chemist, Ilya Prigogine, the psychologist, Jean Piaget, and the economist, Herbert Simon. Hierarchy is a system interconnected in several degrees of behavior, where upward relations are asymmetric to downward relations (Allen and Star, 1982; Haber, 1990). The higher levels control (organize) the lower levels according to time and space constants, presenting a lower frequency of behavior (rhythms with larger cycles) and more stability. Therefore, they help define context and determine the purpose of the lowest levels acting as super-systems (Naveh, 2000, 2001; Wu and David, 2002; Gastó et al. 2005). Ferrater (1979) indicates that there are four types of hierarchy: power, logics, ontological, and axiological. System sustainability relies on these last two hierarchies (Mesarovic et al., 1971).

The creation and evolution of systems, ecosystems, and organisms is expressed as a dissipative structure of hierarchy in natural organization (Gell-Mann, 1995; D’Angelo, 2002). The anthropogenic actions that transform and order the system with economic, social, or natural purposes leads to states different from the previous states where energy dissipation is expressed as a constant. Energy is the fuel that moves the ecosystem, but the operation rate of occurrence in the process is dependent on nutrient availability. The ecosystem operates so as to use the necessary energy available to minimize restrictions of time and space emanating from water and nutrients limitations (Reichle et al., 1975). In this transformation, the state achieved may or may not be sustainable, which implies that there is a stimulus (input) needed to maintain it, avoiding dissipative states different from the states intended by anthropogenic organization.

Hierarchy occurs in multiple systems (e.g., physical, ecological, social, economic, and political systems), thus it is necessary to have a hierarchical theory that allows interaction in multidimensional systems of behaviors and complex structures. In nature, diverse processes of organization occur simultaneously, which are expressed in different scales of time and space (Figure 1). In the highest hierarchical level, there are physical processes leading to the organization of matter in atoms. Furthermore 
there is a chemical organization of the molecules of diverse compounds, which is necessarily subordinate to physical laws; thus chemical organization is expressed as a lower degree in the hierarchy and has less degrees of freedom. The geological process allows organization in rocks, minerals, and their derivatives, and the geomorphological process is subordinated to it. Likewise, biology is constrained by all those levels, in addition to the intrinsic constrains by the biology level itself. Life occurs only when physical, chemical, geological and geomorphologic conditions compose a suitable habitat for it. Integration of the inert with the biological allows a new level of organization: the ecological, as defined by ecosystems through a systemogenesis process, which is dissipative as it is more organized (Gastó, 1980). The degrees of freedom are lower because it is subordinated to all superior hierarchies, in addition to the characteristic ecological hierarchies (Brady, 1994; Wy and Qi, 2000; Wu and David, 2002).

The generation of nature is also the generation of human scenarios; our existence would be unlikely without it. Haber (1990) relates ecosystem artificialization with the types of territory used in bioecosystems, almost-natural ecosystems, semi-natural ecosystems, anthropogenic ecosystems, and technoecosystems. Like in the previous case, social organization is considered a superior hierarchy, which leads to the development of a culture that is inserted into a higher ecological context, which allows adaptation as well as modification. Thus, technology arises as a product of the interaction of nature and society, which corresponds to a new order of matter, energy, and information in other time-space dimensions. In turn, technology allows interaction with the organization of nature and the arrangement of higher anthropogenic levels.

Economy regulates and restricts the transactions occurring in the superior hierarchical levels. Politics, along with economy, are the most restrictive levels of hierarchy. This is where decisions of the organized society are made; therefore, they must be subordinate to all the superior levels. Society actions are focused on the limits of the universal lawfulness of each of the hierarchical levels (Figure 1). As an example, it may be the case that the legislators of a nation decide that the freezing point, zero degrees at sea level, and boiling point of water, one hundred degrees, are now twenty degrees and two hundred, respectively. This would be an illicit decision as physical laws are not subordinate to political or economic laws.

Something similar occurs when economic, technological, or social political decisions are made that exceed the universal lawfulness limits of ecology, as when the capacity of soil use is exceeded, when the indiscriminate harvest of forests or seas occurs, or the expansion of cities goes beyond the threshold that maintains the land system in balance. Examples of this type of transgression are not exclusive to the WesternChristian cultural identity or to current times. Cases of environmental collapse in Easter Island (Rapa Nui; Pontig, 1992), the degradation of the Araucanía (Montalba, 2004; Montalba and Vera, 2006), and the extinction of the Fueguinos (Erlwein, 2001) are worth mentioning. The core problem of sustainability is given by not respecting the highest hierarchical levels, exceeding their limits of universal lawfulness. A good decision must be sound in each and all of the hierarchical levels.

\section{Dimensions and human actions}

There are few topics to compete with the growing recognition of the dependence and human environmental impacts on the biosphere, which are expressed as the key component of our time and spirit when this current period's history is written (Nisbet, 1982; Rosa, 2000), all of which are closely linked with sustainability (Turner, 1973).

Sustainability may be an analytical tool to assess human impacts on the environment, which cannot be separated from the diverse hierarchical dimensions of the phenomenon, which is: (a) anthropocentric, which presents humans as a central axis of the problem; (b) ecocentric, which states that the scenario of human is the central axis, this is, their environment; (c) local, which locates the problem in the direct scale of human actions; and (d) global, where the connections are established in scale of the whole ecosphere. 


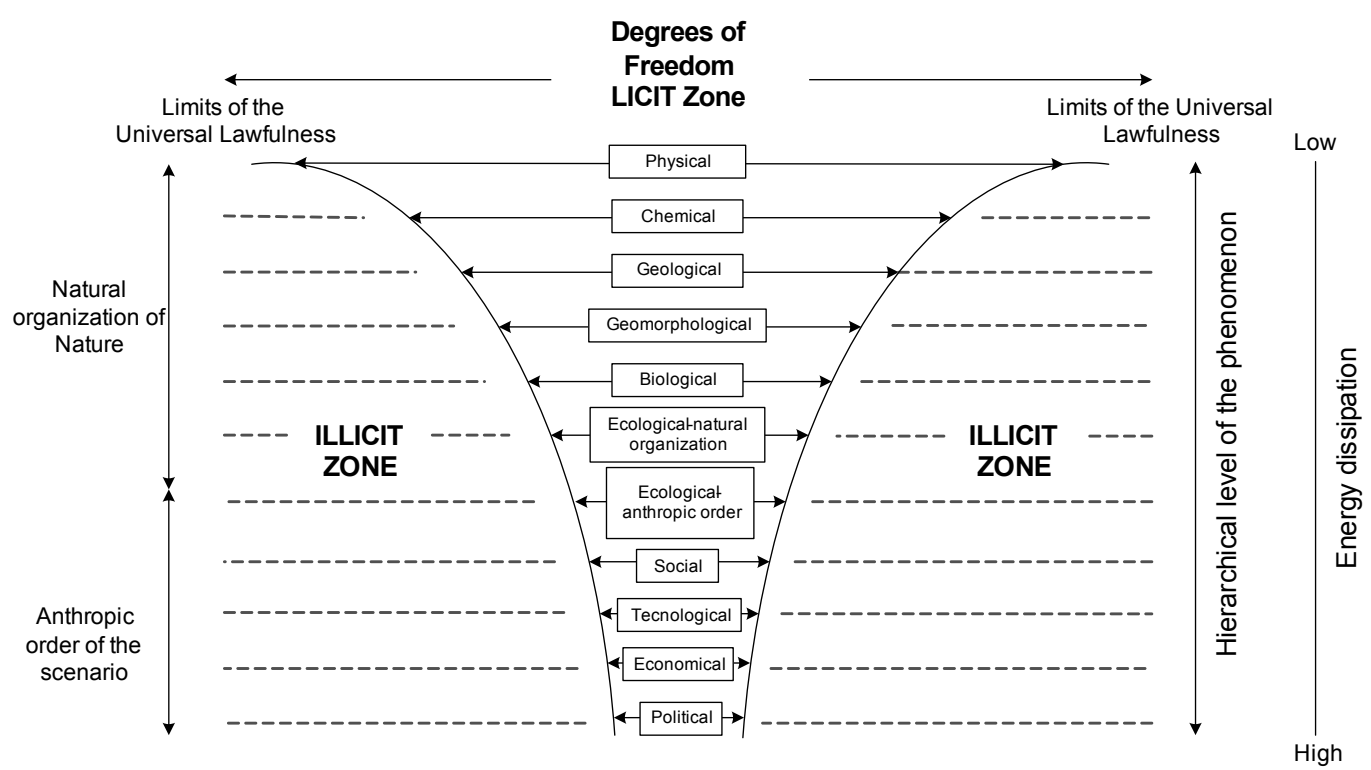

Figure 1. General scheme of the diverse hierarchical levels and their degrees of freedom given by the universal lawfulness of the phenomenon. Physics is the highest hierarchical level followed by chemistry, geology, etc. As the hierarchical level decreases, the degrees of freedom that determines the illicit zone in decision making also decreases. Unsustainability appears if the limits of universal legality are overcome.

Klijn and Udo de Haes (1994) proposed a hierarchical territorial approach that allows gradual change from local to global aspects. The planet is presented as an ecosphere with a cluster of hierarchialized spheres from climate to vegetation and fauna, and from the local to the global through structures and processes. Among these, the transportation of energy and matter, system genesis, and the existence of inferior components and other dependent components are included. This system of hierarchical classification goes from very small scale ecozones to ecoelements in itemized local scales.

In Western culture, closely related to the JudeoChristian tradition, the origin of man is stated as a divine creation. Nature exists to serve man, who receives the mandate to grow and multiply and dominate the land, the birds in the sky, and the fish at the sea, with the unique restriction of not using the tree of forbidden fruit. It is currently impossible to act independently and isolate the ecological systems of the social, as the ecological balance allowing a plentiful life to human is at risk (Low et al., 1999; Redman et al., 2000; Jentoft, 2007).
The general intellectual, moral, and cultural climate of an era (Zeitgeist) is given by the relevance of the anthropocentric and ecocentric dimensions, and the degree of influence of global and local context in the human actions. Therefore, the sustainability of a given system should be approached and analyzed according to the Zeitgeist of the times. There are also other approaches that distinguish or explain different eras in mankind history (Rosa, 2000): Hegel states that each historical period has characteristic topics; Mill introduces the utilitarian and empirical tradition; Comte develops the idea that history is ruled by laws clearly defining the different times such as the Age of Faith, the Age of Reason, the Age of Positive Science and currently, the Age of Environmentalism (where sustainability is placed); Giddens and Beck include risk as a dimension of environmentalism; and Kant states there is a path in order to reach an age and the actions required to be carried out.

The uncontrolled demographic growth reached in the late $20^{\text {th }}$ century, surpasses the capacity of the planet, which affects its sustainability by 
joining both phenomena reciprocally. Therefore, it is possible to relate the contiguous pairs of the four fundamental hierarchical dimensions with four acting axes (Figure 2). Between the local and the anthropocentric are the stakeholders, or civil society, directly managing the phenomenon (Magel, 2000; Queron, 2002). Territory governance arises between the anthropocentric and the global context. This scheme sets the properties and demands of the ruled system (natural and anthropogenic) and the provisions that the ruling system must have (anthropogenic) to give control to the territory (Jentoft, 2007). It also states that the general functions of the ecosystem has to be considered for such effects as the maintenance of zones destined to control greenhouse gases, the regulation and purification of waters, and the conservation of culture (Costanza et al., 1997; Jentoft, 2007). The maintenance and application of global international agreements is centered on the relationship between the ecocentric axis and the globalization of human actions (Naess, 1993a). Whatever the nature of the human actions, they must be conditioned by restrictions of ethical and aesthetical nature, which are located between the local and ecocentric axes. If these factors are not satisfied, system sustainability deteriorates (Van Mansvelt, 1997).

The relationship generated among the four dimensions of the phenomenon and the axis of human actions is created by two virtues: techné and phronesis. The first is technology, which may be a tool as a means to reach a goal, the second is prudence (Vial, 1981). They both deteriorate as the requirements and the rates of element extraction in the ecosystem are raised and violate universal lawfulness by going further against the thresholds of system sustainability. In this context, human presence constitutes an integral part of all ecosystems; its actions are relevant in global impact and deterioration (McDonnell and Pickett, 1993; Vitousek et al., 1997; Lubchenco, 1998). The focal point is the center of divergence from where the position of confluence of the different hierarchical axes intervenes in the human actions and the social agent's decisionmaking are established. Therefore, the natural and cultural generic restrictions are integrated into the territorial restrictions. As a result, new illicit spaces appear, because the solution can be contained in the inner legal space of one of the systems, but outside of other systems.

Actions taken in the landscape affect the sustainability degree of the system. Their nature and intensity come from the theoretical-practical frame accepted by the Zeitgeist of the community, given by the localization in its four hierarchical axes (Rosa, 2000). In the environmental context, the human actions taken over the system are always relevant in relation to its sustainability, an idea that has been expressed for a long time (Lawes, 1847).

\section{Sustaining capacity}

The origin of this concept dates back to the $17^{\text {th }}$ and $18^{\text {th }}$ centuries (Fernández, 1995), coming out of debates in Europe about population growth and food supply (Bartel et al., 1993). In that time (1798), Malthus developed an equation relating population growth with the number of organisms present. In 1830, Verhulst proposed the logistic grow th equation according to the amount of available resources (Freedman, 1980). Finally, Odum (1953) introduced the concept of the asymptote of the logistic curve and related it to the sustaining capacity of the ecosystem (Dhonhot, 1989). The concept was applied to cattle herds in prairies at the beginning of the $20^{\text {th }}$ century, equivalent to the $K$ concept of the logistic model ( $K$ is the population size reached when the population is in balance relative to the logistic growth curve of the population; Odum, 1953). In the 1930s, this concept was applied to wild fauna.

The concept of sustainable forest production was created at the turn of the $19^{\text {th }}$ century, equivalent to the concept of sustaining capacity (Braklacich et al., 1991). The definition states that a harvest must not exceed the growth of forest volume and must ensure the stability of the dependent population. Green (1985) introduced the concept of ecological capacity, with a consistent level of use with no decline of the ecological attributes of the system. This is a formal approach as it relates sustaining capacity with sustainability; if it is exceeded, an unsustainable process develops. The concept has also been applied to human sustaining capacity 


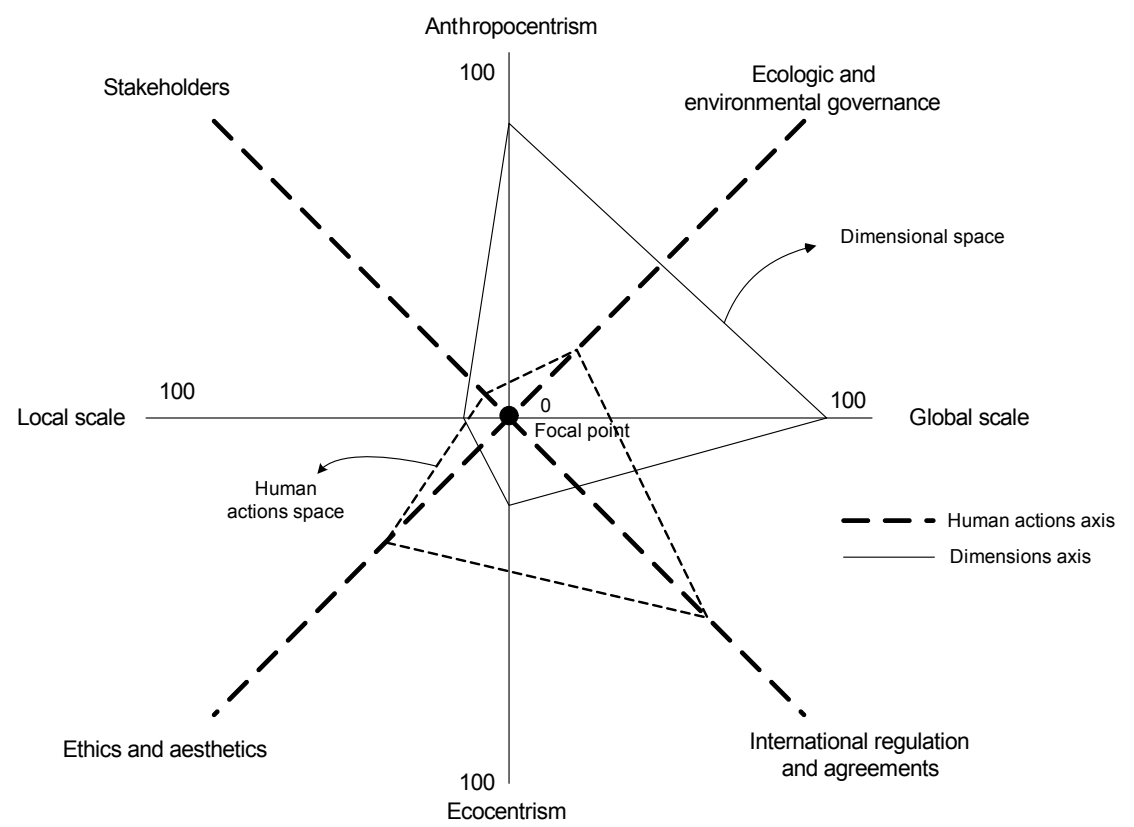

Figure 2. Focus point of the four main hierarchical dimensions that describe phenological sustainability. There are actions and interventions among them, as an example two spaces are presented: one expresses the dimensions focalized on the problem and the other focalizes on the actions taken over the system. There should be a relationship between the dimensions of the problem and the human actions taken.

(Brown et al., 1987; Fernández, 1995). In this case, it is related directly with ecosystemic conservation and the complementary sustainable dimension relative to the anthropogenic capacity. Therefore, they constitute a formal link to sustainability between the anthropogenic and the ecocentric.

In 1977, Nieswand and Pizar (1977) introduced and developed the concept of land use planning capacity, an aptitude measurement of a territory's ability to make room for growth and development, within the limits defined by the structure of the existing ecosystem and resources. According to Goldschalk (1977), this represents a threshold of transfer functions for natural and artificial systems on which the impacts of development may cause an environmental or social degradation. Fernández (1995) indicates that some authors, in relation to the debates on global sustainability and sustainable production, consider sustaining capacity in a wider context (Brown et al., 1987; Braklacich et al., 1991). Thus Naredo (2004) associated the human species with a terrestrial pathology that becomes unsustainable. In violating the limits established for men by nature and history, the industrial society engendered incapacity and suffering while attempting to eliminate incapacity and suffering (Ilich, 1996).

Contributions to the concept and methodology of estimating the sustaining capacity, derived from cattle and fauna management, have been very valuable and have cooperated in the global development of the topic. Dasman (1945) defines it as the number of animals in a specific class and kept in good condition annually, in a grazing unit, without detriment to the forage reserves or the soil. Later, Mott (1960) defines it from another perspective as the amount of cattle supported by the optimal grazing pressure. Scharnecchia (1990) introduces two concepts not considered in the previous definitions; management and specific objectives, but does not include ecosystemic sustainability. The previous may be extended to generic sustainability, if human pressure is used instead of cattle pressure, and prairies are replaced by the ecosphere. 
Fernández (1995), supplies a generic connotation to the concept, after making a concise review based on the evolution and eligibility of them. The sustaining capacity of the ecosystem is defined as the intensity of use that the ecosystem may support, submitted to a certain action, maintaining its state. Formally, Fernández (1995) expresses this concept as:

$$
\mathrm{CS}=f\left(\Sigma, \pi, \mathrm{E}_{\mathrm{j}}, \sigma_{\mathrm{r}}\right)
$$

where $\Sigma$ represents the ecosystem and its characteristics, $\pi$ is the action that human exerts on the ecosystem through technology (artificialization operator), $\mathrm{E}_{\mathrm{j}}$ is the ecosystem state, and $\sigma_{\mathrm{r}}$ is the set of ecosystem resources.

\section{Organization and order}

Margalef (1958) introduced the theory of information in ecology. This theory and its methods were used to evaluate the organization or disorder of a system. In this context, the information and diversity in the components' order may be considered as equals, at least from a practical point of view. Mathematically, information (I) is described by the following equation:

$$
\mathrm{I}=\mathrm{K}^{*} \ln \mathrm{R}
$$

where $\mathrm{K}$ is a constant and $\mathrm{R}$ is the number of choices possible and equally probable. The concept of diversity in ecology has its roots in the richness of species or general components and depends on the system capacity to discriminate among them, which then depends on the capacity to discriminate among individuals, species, and genotypes (Margalef, 1969). Similarly, the concept of ecodiversity expands the notion of diversity including components of climate, geomorphology, site, and water, among other parameters of a basin. In the development of a hydrographical basin, or any ecosystem in particular, mechanisms of organized energy accumulation work to reach higher maturity or development states, like in genetic systems. All these systems are cybernetic in nature by their capacity of self-created organization in response to changes in the internal and external medium (Von Bertalanffy, 1975; Maturana and Varela,
1992). The information is expressed by mechanisms and information storage implies increasing the mechanism's complexity. Mechanism efficiency increases as the organized complexity increases (Margalef, 1969).

Natural drift contributes information to the system (Maturana and Mpodozis, 2001). The best conformed systems are able to select information so as to retain pertinent information and reject inappropriate information, increasing their level of complexity. It may be deduced, according to general cybernetic theory that any system adopting diverse states remains automatically in the most stable level according to circumstances. Any animal or vegetable species may be considered to contain information, and therefore when it enters a system the total complexity and information of it increases. The inorganic elements of the system, such as soil particles or water droplets, also contain information. Taking the previous ideas to their limit, Wilson (1968) proposes the order principle, where the organization reached by a system tends to extend and prolong towards a more stable and complex system through the natural drift. Natural drift and selection mechanisms of order selection operate to accumulate the amount of information until they reach a limit.

The process of systemogenic change is ruled by known laws and principles. It is ordered, gradual, and directed to a more organized state to reach a state of balance at the climax (Gastó, 1980). In mature ecological systems (the climax), there is a greater complexity than in previous immature states. They present a greater diversity of organisms and structures of all classes, as well as a greater complexity of relations among organisms. In turn, the energy flow that crosses mature systems tends to be slower and the carbon persistence, whose cycle accompanies that flow, tends to be higher (González, 1981). The natural organization of the system is generally altered by human activities of system artificialization, which necessarily implies the application of matter inputs, energy, and information from other ecosystems and a change of numerous fundamental attributes.

The anthropogenic transformation from natural ecosystems into artificial ecosystems implies 
changing from mature natural states to states of lower complexity and maturity, simplifying and disorganizing a natural system by means of exploitation or the disturbance of its cycles, such as what occurs with agriculture sensu lato (any artificial activity of nature) (Margalef, 1963; Cooke, 1967; Odum, 1969; González, 1981). Its fundamental structures and processes are modified, which may be grouped into community energy, nutrients cycle, efficiency, homeostasis, water, vital history, and structure. The contribution of external inputs to the system and anthropic control are fundamental to maintain the sustainability of an anthropic arrangement of a system complexity in a dynamic balance state. In this context, D'Angelo (2002) points out the contrast between the paradigm of system equilibrium, which establishes the balance of nature (homeostatic system: first order cybernetics), and the paradigm of non-equilibrium systems (autopoietic adaptive system: second order cybernetics). This last system considers the existence of discontinuities and surprises in the system environment and the fact that they work far out of balance with a capacity to adapt and self-organize (Costanza et al., 1991). The application of an evolving perspective of the thermodynamic system sets up a crucial point for the development of a paradigm alternative to balance, such as the pioneering work by Prigogine and Stengar (1984) on thermodynamics of imbalance. The Complex Adaptive System (GellMann, 1995) is a model appropriate for the ecological and social phenomena that make up the imbalance paradigm, such as agriculture, rurality, and sustainability.

A general model of the dynamics of complex systems proposed by Holling (Costanza et al., 1993) places an emphasis on the temporal dimension of the problem. This model describes the system dynamics in four fundamental phases: exploitation, maturation, liberation, and reorganization, which are arranged in two axes. One refers to accumulated capital and the other to connectivity (Figure 3 ). This cycle reflects the magnitude of changes in accumulated capital such as nutrients, carbon, energy, and information, and the connections expressed as matter transportation, energy, and information, occurring in each change of state. The external connections through contribution and input extrac- tion must be considered in this process where system reorganization corresponds to a restoration of the order, reaching a new and sustainable balance versus a changing environment.

D'Angelo (2002) includes the development stages of a system in stable periods to the model of the complex system dynamics, from the formal properties of the Von Bertalanffy cybernetic systems. This model relates the degree of organization with time and development of the synchrony and diachronic of system rhythms. Thus, in the context of the imbalance paradigm, the following may be stated: a) in the dynamics of all complex system; including the property, rural, and regional system and in a communal, regional, or world scale, periods of relative stability in the environment conditions interchange with unstable periods; and b) during the stability period, the continuity of the system demands a progressive adjustment through three consecutive stages: the total indifference of the components, the progressive segregation in subsystems, and the subsystems mechanization and centralization determining the order. During the readjustment period, the system depends on experience and flexibility to adequately change to new circumstances, so as to permanently maintain a viable state, or collapse. Thus, it is possible to say that sustainability depends partially on the adaptive flexibility of the system and partially on its memory.

The order and sustainability of any agricultural system, including the property, rural, and regional systems, are linked with continuity in time. Such continuity requires that the human actions are exerted on the system in a local or regional scale and may generate a sustainable or unsustainable state, balanced and adjusted to the conditions of a changing environment. When this is modified, decision-making and human actions must express the essential flexibility to transform from an organizational mode to another corresponding to the new environment configuration.

As the natural landscape expressed through climate, geoform, site, vegetation, use, culture, and others, differs from one place to another, the flexibility and order of a sustainable system must be adequately symmetrical to the variabil- 
ity of its environment. This may be represented as the Capacity of Use of the Ecosystem, which depends on the technological vulnerability and receptivity of the environment considered, and its relations to change as the Adaptive Complex System (Gastó et al., 1997). Desertification, erosion, contamination, degradation of local cultures, noise pollution, are only some of the most simple examples to observe sustainability deterioration, when it is not blocked with adequate actions (Gastó, 1993). In more fragile environments, it is necessarily to include a higher amount of inputs from other ecosystems to maintain a sustainable state of the system, generating a greater ecological footprint, ecological load, and transportation distance (Wackernagel and Rees, 2001). In less fragile environments, natural stability allows a higher degree of artificialization without sustainability deterioration (Gastó et al., 1997).

\section{Order determinants}

The land use planning and design consists of the organization of components, structures, and functions in an ecological system which searches for a correct and harmonic relation among them and with the system as a whole. In a topological arrangement of extraction and introduction of elements based on Landscape Ecology, a cluster of patches mutually interconnected are inserted onto the background matrix through corridors so as to constitute a unit or a whole (Forman and Godron, 1986; Forman, 1995). Landscape ecology is a discipline that sets the boundaries of human actions (limitations and opportunities), the dimensions, and goals of the social agents which occupy and use a territory and the interaction between them.

As countries develop and grow in a magnitude never seen before, the arrangement needs are greater as the population growths and the growth of demand increase, a result of higher needs and functions to be satisfied by land resources, according to Malthus (1798) theory. The massive development of science, ecology, and economy as a result of investigation and cultural development have influenced human actions on a territory that are against agriculture sustainability, rurality, and urban planning, and the conditions essential for the development of quality life.

The objectives and the human actions carried out are not neutral; they are a product of a culture generating new landscapes for life when acting on the natural organization, which in turn, affects life itself. Desertification is a relevant case of deteriorating human actions leading to the development of agri deserti, which in turn negatively affects human development. Therefore, it inserts into the generic process of system degradation which then becomes unsustainable.

In land use planning and design, where the urban, rural, and natural aspects are integral, there are three objectives determining economic order: economical objectives of production, ecological objectives of nature, and social objectives of the agents (Nijkamp et al., 1990). The order determinant may be only one, or a weighted combination of the three, which requires the determination of a solution space to set their best combination (D'Angelo, 2002; Figure 4). According to the limitations and potentials of each site in particular, the lawful solution space changes in position (Figure 5).

The economic determinants of land use planning and design for agriculture establish their objectives and human actions based on what produces the greatest economic benefits. It relates to decision-making which leads to a transformation of the territory in an industry producing goods and services of commercial value (Costanza et al., 1991; Martínez-Alier and Roca, 2000). In that transformation, it is equivalent to a factory of agricultural products, and it is supported by principles such as the economy of scale, which increases efficiency on developing operations of greater magnitude and simplicity. This reduces a system's diversity to a minimum, which then enters into conflict with the other order determinants. The efficiency in the use of manual labor is also determined, which affects a dramatic reduction of employment and rural life. Limitations to the use of fossil fuel energy are not introduced to make a productive and sustainable system. The use of pesticides or fertilizers of any kind is not limited, unless they are established by law. Capital must be used to 


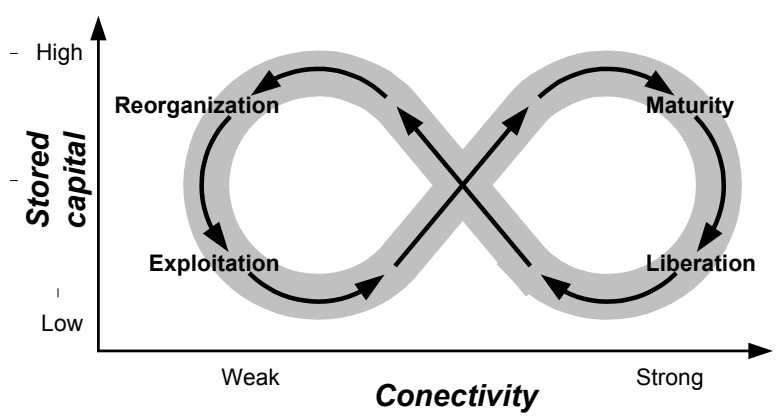

Figure 3. General model proposed by Holling (1988) in relation to the dynamic of complex systems. The cycles represent changes in two attributes through four stages: exploitation, maturity, liberation, and reorganization. The abscissa indicates the degree of connectivity (organization, complexity) between the elements and subsystems of the system. The ordinate indicates the quantity of human resources accumulated by the system.

ensure the highest rate of return, thus the short term is favored over the long term, and the measures of nature conservation are reduced to a minimum as they do not have any effect on economic benefits (Subercaseaux, 2007). However, there are some attempts to favor ecological long term sustainability over economical short term return (Barber, 2006).

The environmentalist determinants of order in land use planning and design are focused on natural conservation at the highest possible level. Harmony attributes exist among the diverse components of the ecosystem and favor the natural rhythms related with species biology and trophic natural chains, and the biogeochemical cycles relative to the recirculation of natural and artificial waste of the ecosystem. Biodiversity develops in all dimensions and the system must work based on solar energy. Agrochemical products affecting usual ecosystem activity are not included and only innocuous organic substances are allowed. The sounds and scents specific to nature are valued. Natural conservation of the system is one of the primary objectives; therefore the long term is an essential condition.

The social constraints of a land use planning and design restrict the use of territory, so as to structure it according to the social agents' requirements. Decisions are taken for the location of human settlements in the best places for life quality, like those where climatic and geomorphological conditions are ideal. Additionally, the sanitary conditions must be adequate for life and the resources essential for their material supply must exist.

Low biodiversity, as it occurs in high productivity commercial agricultural systems, occurs in highly-subsided systems by auxiliary, highquality energy flows, like that from fossil fuels, and by high nutrients consumption; while high biodiversity is associated with a low level of external inputs, dependent on internal nutrients recycling (Odum, 1975). The price of developing agricultural-commercial high-potential ecosystems is an increase on the costs of land use planning and design and systems management. The Green Revolution is associated with this process of productive increase (Winkelmann, 1993).

These three dimensions can't be maximized simultaneously, as they are mutually exclusive to a high degree. Therefore, thresholds must be established in each case allowing for the conditioning of transfer functions, between one and another dimension, allowing the establishment of the ideal solution space as indicated in Figures 4 and 5. The search for a solution first requires an ontological approach to the problem, which allows for a dependence on a complete ad hoc knowledge of the landscape where the 
land use planning and design actions of the territory are carried out. The subsequent analysis must include the four fundamental axiological dimensions of land use planning and design, namely the functional, aesthetical, ecological, and vital dimensions. The result of this analysis must allow for the achievement of a location of lawful space and an optimal solution point for determining a harmonic position of integration and compatibility of the three dimensions of order (Ohrens et al., 2007).

\section{Cultural landscape}

Cataldi, a mathematician and designer of Bologna, stated in the $16^{\text {th }}$ century that humans modify nature until it is gradually transformed into their cultural landscape. Thus, a sustainable landscape is generated if actions are carried out to allow the development of an environment compatible with its quality of conservation, life, and other attributes of interaction among them. In contrast, the system becomes unsustainable when the process of desertification develops (Gastó, 1993).

The cultural landscape may be defined as what is left after human action on the territory (De Bolos et al., 1992; Gastó et al., 2006). Therefore it is a product of human activity on nature, a process conditioned by the culture of a social agent. The human action occur in all hierarchical levels of the phenomenon (Figure 1) and surpasses the universal lawfulness in most of them, from the highest levels, such as the chemical level causing salinization and fertility loss; the geomorphological level causing erosion; the biological level causing biodiversity reduction; and the ecological-natural level, affecting the rhythms and harmony of the agricultural and rural ecosystem. The highest impact, however, occurs in the inferior hierarchies, where ecological-natural organization is altered for the generation of an ecological-anthropogenic order, which is the cultural landscape. In the social level, for example, if the location of human settlements doesn't consider the natural constrains of the landscape (its ecological-natural organization: relief, water availability, natural disturbances) it is unlikely to be able to supply proper urban services (e.g., water and energy supply) and be sustainable. Also, if technology is not subordinated to the hierarchical constrains (natural and social), the cultural landscape tends to be degraded as it happens for example when the roads constructed or the clear cutting of woods cause soil erosion, and the misuse of chemical fertilizers pollute groundwater. The economical level, on the other hand, when giving a value to different products and services, usually distorts the decision making process favoring the profits over the sustainability of the system. Politics, of inferior hierarchy has a greater factum power, legislates and imposes actions on superior levels of the hierarchy, frequently exceeding the limits of universal lawfulness. Therefore the cultural landscape may become unsustainable.

The concept of culture can be defined as how human communities interpret, symbolize, and transform their environment. Interpreting their environment as a local or global limit concept, they make sense to their actions to achieve a new, general, ordered configuration of the system as a unique unit. In simpler words, culture is a way to relate to the world. This can include science, technology, religion, myths, art, customs, languages, beauty, and a sense of belonging. Likewise, the cultural landscape is an anthropic creation. Finally, there is a cultural component, which forges through multiple human actions such as: urbanism, industry, crops, forestry, cattle, transportation, fishing, mining, and others. These human actions result in the generation of designed landscapes or residual landscapes (Gastó et al., 2006). In this context, the concept of nature has evolved historically in science, from the time of Darwin, from environmental determinism through mutual determination and possibilities, to the cultural landscape. Subsequently, it has evolved to other concepts such as abstract space, technocentric context, ecocentric context, exploited nature, and second nature (Vargas, 2005). Any approach is strongly related to agriculture and sustainability.

The final rationale of the social agents, as cognitive agents, is maintaining the structural coupling with their domains of existence (Maturana and Varela, 1972, 1992; Röling, 2000). In this context, the mutual determinants maintaining this coevolved coupling between the social agent 


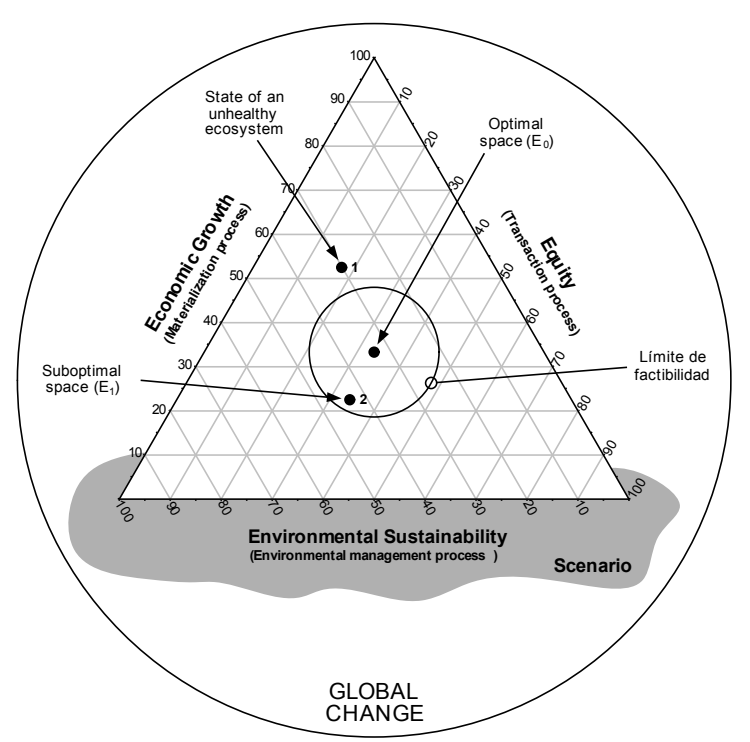

Figure 4. Scheme indicating the localization, in functions, of the three different determinants of order: economical, ecological, and social. These generate the cultural landscape that can be sustainable if the best combination among them is established. In contrast, there is a degree of unsustainability due to the topological distance to the next optimal stage (Gastó et al., 1997).

and its landscape, are of an emotional nature (Plutchik, 2001). The agent experiments with emotions in the presence of the phenomenon they perceive, and this determines the human actions that generate the landscape, which in turns gives feedback to their perception (Capra, 1996). Paraphrasing Cataldi, by this mechanism the cultural landscape reciprocally models man who becomes an actor within a coevolving context of mutual determinants (Vera, 2006).

\section{Agriculture, rurality, comarca, and region}

There are many ways to define agriculture. Lawes (1847) defines it as the process of nature artificialization that has a specific objective such as producing food, fibers, leather, wood, or landscape aesthetics. Therefore, it involves a process of transformation, a social agent, and a specific objective. In this context, agriculture sensu lato covers numerous activities related with the multiple use of land with production purposes (farming, forestry, aquaculture, livestock, among others), protection (soils, fauna, shores, landscapes, among others), and recreation (horseback riding, kayaking, trekking, sport fishing, among others). For each, society takes part in numerous activities, generating changes in the agricultural landscape (Meeus et al., 1990).

According to Röling (2000), the cognitive support of collective decision-making is measured in four components: values, theory, context, and action (Figure 6). According to the definition given by Lawes (1847), values must be based on an ecological rationale based on principles, laws, and ecosystemic structures. Therefore, any agriculture style must fulfill all the attributes of sustainability and operability. Theoretically, the model must be constructivist; therefore it could be generated within an epistemological frame of collective subjectivity. Consistently, action must be deliberate and collective according to the culture of social agents and the perception on constraints specific to nature. Finally, the context of agriculture must be focused on humans as the greatest force of nature generating the cultural landscape in their environment, therefore the future is a human artifact. However, the high demographic concentration and the usual unadvised use of technology provides evidence that we lack an intellectual instrument allowing us to agree with this force (Lubchenco, 1998). If of Lawes definition is replaced with a productivity definition of agriculture, the four dimensions of the cognitive support of the collective decision- 


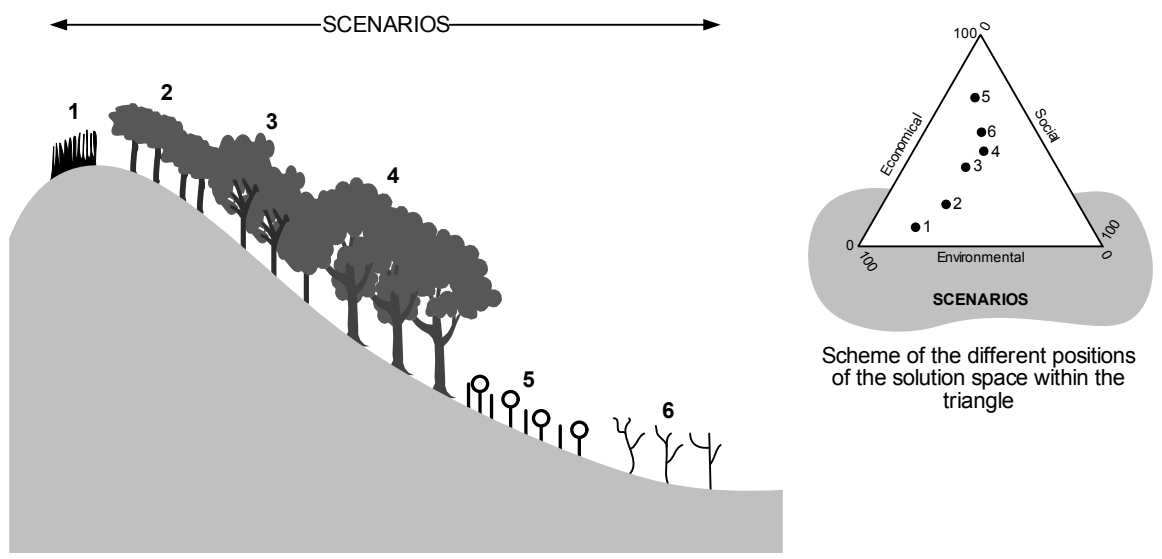

Figure 5. Economical, environmental, and social order determinants and a scheme of relative superposition according to geo-form and place characteristics (Gastó et al., 1997).

making are fundamentally modified. As a consequence, the emerging actions are inclined to generate situations of landscape unsustainability. The definition of agriculture that is used is crucial for the paradigm that governs the human actions over the cultural landscape and its degree of sustainability.

From an ontological point of view of language, in Spanish the word agriculture has a rather restricted meaning to indicate land tilling and land crop tilling. In contrast, in English, there is a substantial difference between cropping and husbandry (while in Spanish they are analogous with agriculture), and farming and ranching, since these last two concepts clearly have a territorial connotation. In Spanish, there are no words to express those concepts. A new verb would have to be coined, such as "prediar" derived from predio (farm) or "fincar" derived from finca (farm). English expressions such as "farming and the fate of wild nature" are only justified in a context of order, management, and territorial, farm, or regional administration (Imhoff and Baumgartner, 2006). From the operative point of view, farm (ranch, country state, common land, community, country house, plot, national park or any other) may be defined as an organized territorial unit of decision making, that consist in a renewable natural resources space is connected internally and limited externally with the goal to make agriculture (Ruthenberg, 1980; Gastó et al., 1984). Artificialization of nature contained in the farm a is result of the application of transformation operations on resources contained in the farm space-time, diversified in both dimensions and generating a cultural landscape farm that may be sustainable or unsustainable.

Etymologically, 'rural' in different early European languages (Amestic, Icelandic, Avwis, Tocario, Latin, Scottish, and Welsh) means open space. The essence of rurality is the opening of lands that were originally forest and prairies, where numerous social agents are inserted in fulfillment of the most diverse functions. Agriculture, in turn, is a more recently coined term, in the year 1440, when the era of specialization and the spread of technology with productive purposes began, but without a territorial connotation. It is convenient to state that agriculture, as rurality, is an abstract expression without a territorial connotation; on the contrary, farm and comarca (a region connected through a common local market) have both, respectively, a territorial connotation. In the farm and the $\mathrm{co}$ marca context, agriculture and rurality correspond to the undertaken actions after society's decision-making, to achieve a certain response or output of the system.

Agriculture is necessarily integrated with the urban and wild aspects. Therefore, traditional economy (emerging fundamentally from the urban aspect) produces a feedback affecting all dimensions, especially in the scales of human actions, trading, and population feeding. Cur- 
rently, eating well means that quality must be generated for the population as well as for the land we live in. In addition, it means that the process is sustainable, thus, local production, with low inputs, high diversity, minimal environmental impacts, and minimal transportation and elaboration costs, must be fostered (Boco et al., 2006).

\section{Final remarks}

Agriculture sustainability and rurality in the $21^{\text {st }}$ century requires searching for a new paradigm. This paradigm should be focused on the space-time scale. This is given by farm and $\mathrm{co}$ marca, or any of the relevant scales of time and space, from local to the global aspects, in their respective rhythms and flows of the human actions of different social groups. The final product should be evaluated based on a combination of labor, cultural landscape, production, conservation, and sustainability, instead of traditional parameters focused on politics, economics, and technology.

Agriculture sustainability and rurality are expressed in multiple types and levels given by the dimensions of the objectives and goals established by the anthropocentric, ecocentric, local, and global aspects. In each case, the focus corresponding to the specific area of intended sustainability needs to be determined. This is expressed in degrees of intensity and scale. The magnitude of the sustainability degree, on the contrary, is given by society's actions, the governance determinants of the local and global agreements, and the ethical and aesthetic restrictions imposed to the system by society.

The land use planning and design of wild territory is focused on three different constraints supporting human actions: praxis, which are those justified by themselves, such as rural- ity; poiesis, which are those justified for other purposes, such as the "food factories"; and by saltus, corresponding to territories freed from human intervention, such as wild areas.

The natural organization of ecological systems occurs in multiple hierarchies, where each is ruled by defined principles and laws and is expressed in different states without exceeding the limits of universal lawfulness and sustainable energy costs, matter, and information. On the contrary, the order given by humans in land use planning and design are adjusted in each case to the needs and functions self-imposed by society, which may be capricious or indiscreet, frequently exceeding the sustaining capacity of the system. Maintenance of the new system order imposed by society requires the application of matter inputs, energy, and information from other places and times. This is expressed through the ecological footprint, ecological load, and transportation distance (Wackernagel and Rees, 2001). In current society, the different orders in land use planning and design given by men, have in common an additional energy cost from transformations, implying a high expense of fossil energy, which is usually lower in natural systems, medium in the rural system, and high in urban and industrial systems. The change of state generated by the artificialization of natural systems to anthropic systems of agricultural and rural nature implies human actions imposed by the determinants of economic, social, or natural order leading to a new cultural landscape. This has an implicit additional cost of sustainability, which varies according to the objectives and goals established and the restrictions and capacities of the system's load and unloading (Figure 7). The background topic is the topological distance established between the natural organization of the system and the human order. Culture and natural constraints are a central part of the problem, therefore land will be as men are. 


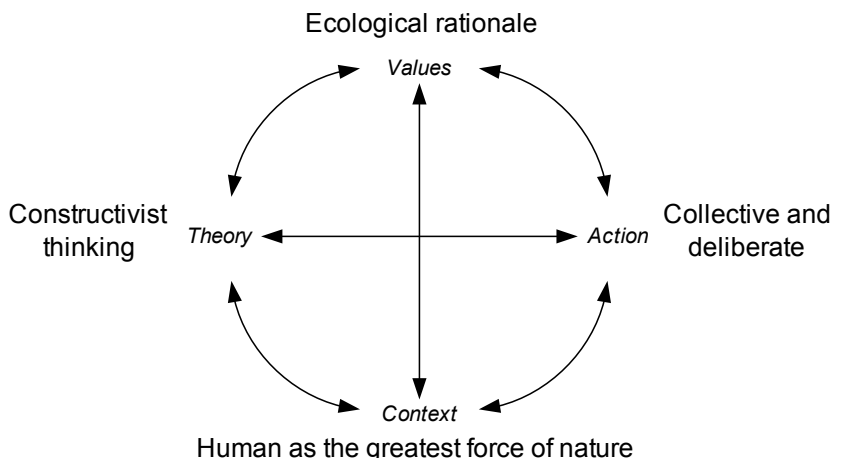

Human as the greatest force of nature Future is a human artefact

Figure 6. Diagram for the cognitive support of decision-making in agriculture based on the definition of Lawes (1847) as nature (Röling, 2000).

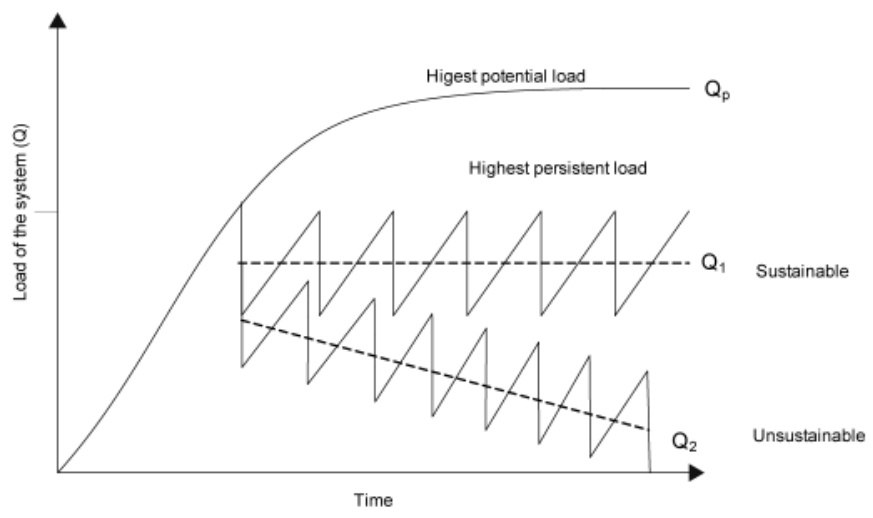

Figure 7. Generalized representation of the highest potential load of any system and its variations on the basis of objectives and management (Reichle et al., 1975).

\section{Resumen}

\section{J. Gastó, L. Vera, L. Vieli y R. Montalba. 2009. Sustentabilidad de la Agricultura: Conceptos} unificadores. Cien. Inv. Agr. 36(1): 5-26. Este trabajo es el producto de un largo proceso para reunir y analizar los principia involucrados en la sustentablidad de la agricultura. Consideramos que estos principia son cruciales para el desarrollo sistemático, riguroso y consistente de la agricultura sustentable. Los conceptos unificadores de la agricultura sustentable se clasifican en siete principios fundamentales: (i) existe una relación jerárquica en las tomas de decisiones con respecto a las acciones del hombre sobre el paisaje y en ambiente; (ii) el impacto del hombre sobre la tierra se debe analizar desde diferentes perspectivas (local, global, antropocéntrica y ecocéntrica); (iii) la carga poblacional, en un contexto agrario, es fundamental en el diseño y manejo del ecosistema; (iv) el hombre arregla la naturaleza con escasa consideración de su propia organización natural; (v) la planificación y diseño del uso de la tierra están subordinados al orden de determinantes que ocurren en situaciones particulares; (vi) el paisajismo cultural es 
el resultado de la acción humana; y (vii) los conceptos de agricultura y ruralidad carecen de una connotación territorial; a diferencia de la granja y de la comarca (región conectada a través de un mercado local común). Finalmente, agricultura sustentable debe ser abordada desde varios aspectos, con énfasis en la naturaleza y la cultura como factores determinantes.

Palabras clave: Agricultura, naturaleza, paisajismo cultural, sustentabilidad, territorio.

\section{References}

Allen, T., and T.B. Star. 1982. Hierarchy: perspectives for ecological complexity. The University of Chicago Press. Chicago, IL, USA. 310 pp.

Alonso, A., and E. Sevilla, 1995. El discurso ecotecnocrático de la sostenibilidad. Pages 93-119. In: A. Cadenas (ed.). Agricultura y Desarrollo Sostenible. MAPA. Madrid, Spain.

Altieri, M. 1999. Agroecología, Bases Científicas para una Agricultura Sustentable. Nordan-Comunidad. Montevideo, Uruguay. 338 pp.

Altieri, M., and A. Rojas. 1999. Ecological impacts of Chile's neoliberal policies, with special emphasis on agroecosystems. Environmental, Development and Sustainability 1:55-72.

Anonym. 1991. Manual de conservación del suelo y del agua. Tercera Edición, SARH, SPP. Colegio de Postgraduados. Chapingo, México. 574 p.

Aubreville, A. 1949. Climats, forêts et desertification de l'Afrique tropicale. Société d'Editions Géographiques, Maritimes et Coloniales. París, France. 361 pp.

Barber, D. 2006. Will agricultural economics change in time? Pages 210-213. In: D. Imhoff, and J. Baumgartner (eds.). Farming and the Fate of Wild Nature. Watershed Media. Healdsburg, CA, USA.

Barney, G. 1982. El Mundo en el Año 2000. En los Albores del Siglo XXI. Informe Técnico. Tecnos. Madrid, Spain. 985 pp.

Bartel, G., B. Norton, and G. Perrier. 1993. An examination of the carrying capacity concept. Pages 89-103. In: H. Roy, R. Behnke (Jr.), I. Scoones and C. Kerven (eds.). Range Ecology at Disequilibrium: New Models of Natural Variability and Pastoral Adaptation in African Savannas. Overseas Development Institute. London, UK. 248 pp.

Boco, J., A. Jabine, G. Schueller, and D. Seidman. 2006. A taste for conservation. p. 214-223. In: D. Imhoff, and J. Baumgartner. Farming and the
Fate of Wild Nature. Watershed Media. Healdsburg, CA, USA.

Bohm, D., and F. Peat. 1987. Science, Order and Creativity. A Dramatic Look al the Roots of Science and Life. Bantam Books. NY, USA. 280 p.

Brady, R. 1994. Pattern description, process explanation, and history of morphological sciences. $p$. 7-31. In: L. Grand, and O. Rieppel. Interpreting the Hierarchy of Nature: Transystemic Patterns to Evolutionary Process Theories. Academic Press. San Diego. California, USA.

Braklacich, M., C. Bryant, and B. Smith. 1991. Review and appraisal of concept of sustainable food production systems. Environmental Management 15:1-14.

Brown, B., M. Hanson, D. Liverman, and R. Maredith. 1987. Global sustainability: toward a definition. Environmental Management 11:713-719.

Capra, F. 1996. La trama de la vida. Una nueva perspectiva de los sistemas vivos. Editorial Anagrama. Barcelona, Spain. 359 p.

CMMD. Comisión Mundial del Medio Ambiente y Desarrollo. 1987. Nuestro futuro común. CMMD (Comisión Mundial del Medio Ambiente y Desarrollo). Alianza. Madrid, Spain. 460 pp.

Cooke, G. 1967. The pattern of autotrophic succession in laboratory microcosm. Bioscience 17:717-721.

Costanza, R., H. Daly, and H. Bartholomew. 1991. Goals, agenda, and policy recommendations for ecological economics. p. 1-20. In: R. Costanza (ed.). Ecological Economics. The Science and Management of Sustainability. Columbia University Press. NY, USA.

Costanza R., R. D’Arge, R. de Groot, S. Farber, M. Grasso, B. Hannon, K. Limburg, S. Naeem, R. O’Neil, J. Paruelo, R. Raskin, P. Sutton, and M. Van den Belt. 1997. The value of the world's ecosystem services and natural capital. Nature 387:253-260.

Costanza R., L. Wainger, C. Folke and K. Mäler. 1993. Modeling complex ecological economic systems. BioScience 43:545-555. 
D'Angelo, C. 2002. Marco conceptual para la ordenación de predios rurales. p. 205-223. In: Gastó, J., P. Rodrigo, and I. Aránguiz (eds.). Ordenación Territorial, Desarrollo de Predios y Comunas Rurales. Facultad de Agronomía e Ingeniería Forestal, Pontifica Universidad Católica de Chile. LOM Ediciones. Santiago, Chile.

Dasman, W. 1945. A method for estimating carrying capacity of rangelands. J. Forestry 43:400-402.

De Bolós, M. 1992. Manual de Ciencia del Paisaje: Teoría, métodos y aplicaciones. Masson. Barcelona. Spain. 273 pp.

Dhonhot, A. 1989. Carrying capacity: a confusing concept. Acta Oecologica 9:337-346.

Dregne, H. 1978. Desertification: man's abuse of the land. Journal Soil and Water Conservation 33:1114.

Dregne, H. 1987. Soil erosion: cause and effect. Land Use Policy 4:412-418.

Erlwein, A. 2001. The extinction of the Fuegians, an example of the western crisis of perception. Essay Master of Science in Holistic Sciences. Schumacher College, Dartington, UK. 15 pp.

Fernández, P. 1995. Metodología para Determinar la Capacidad Sustentadora Animal en un Contexto de Uso Múltiple. Aplicación al Ecosistema Mediterráneo. Tesis Doctoral. Escuela Técnica Superior de Ingenieros Agrónomos y de Montes. Universidad de Córdoba. Córdoba, Spain. 220 pp.

Ferrater, J. 1979. Diccionario de Filosofía. Ariel. Barcelona, Spain. 3.589 p.

Forman R. 1995. Land Mosaics: the ecology of landscapes and regions. Cambridge University Press. Cambridge, UK. 612 pp.

Forman, R., and M. Godron. 1986. Landscape Ecology. John Wiley and Sons. NY, USA. 618 pp.

Freedman, H. 1980. Deterministic Mathematical Models in Population Ecology. Marcel Dekkar Inc. NY, USA. 254 pp.

Gastó, J. 1980. Ecología, la Transformación de la Naturaleza. Editorial Universitaria. Santiago, Chile. 563 pp.

Gastó, J. 1993. La desertificación: los posibles elementos de lucha. Páginas 47-77. In: J. Cubero y M. Morero (eds.). La Agricultura del Siglo XXI. Mundi-Prensa. Madrid, Spain.

Gastó J., R. Armijo, and R. Nava. 1984. Bases heurísticas del diseño predial. Sistemas en Agricultura. IISA 8407. Departamento de Zootecnia. Facultad de Agronomía e Ingeniería Forestal. Pontificia
Universidad Católica de Chile. Santiago, Chile. $41 \mathrm{pp}$.

Gastó J., P. Rodrigo, and I. Aránguiz. 2002. Desarrollo de una metodología para la representación y resolución de problemas de predios rurales. $\mathrm{Pa}$ ges 111-151. In: Gastó J., P. Rodrigo e I. Aránguiz (eds.). Ordenación Territorial, Desarrollo de Predios y Comunas Rurales. Facultad de Agronomía e Ingeniería Forestal, Pontificia Universidad Católica de Chile. LOM Ediciones. Santiago, Chile.

Gastó J., M. Pino, V. Fuentes, S. Donoso, S. Gallardo, N. Ahumada, C. Gálvez, C. Gatica, M. Retamal, C. Pérez, and L. Vera. 2005. Metodologías para la Planificación Territorial. Ministerio de Cooperación y Planificación. Santiago, Chile. 144 pp.

Gastó, J., L. Vélez, and C. D’Angelo. 1997. Gestión de recursos vulnerables y degradados. Pages 77116. In: E. Viglizzo (ed.). Elementos para una Política Agroambiental en el Cono Sur. PROCISUR del Instituto Interamericano de Cooperación para la Agricultura IICH. Libro Verde. Montevideo, Uruguay.

Gastó, J., L. Vieli, and L. Vera. 2006. Paisaje Cultural, de la Silva al Ager. Agronomía y Forestal UC (Chile) 28:29-33.

Gell-Mann, M. 1995. El Quark y el Jaguar. Aventuras en lo Simple y en lo Complejo. Tusquets Editores S.A. Barcelona, Spain. 413 p.

Glantz, M. H., and N. S. Orlovsky. 1983. Desertification: A review of the concept. Desertification Control Bulletin 9:15-22.

Goldschalk, D. 1977. Carrying capacity: a promising growth management tool. Pages 10-11. In: Environmental Comment. The Urban Land Institute. Washington DC., USA.

Gómez, J. (ed.). 1981. El Tiempo en las Ciencias. Problemas Fundamentales del Hombre. Enfoque Interdisciplinario. Editorial Universitaria. Santiago, Chile. 216 pp.

González, F. 1981. Ecología y Paisaje. H. Blume Ediciones. Madrid, Spain. 250 p.

Green, B. 1985. Countryside conservation. The protection and management of amenity ecosystem. The Resource Management 11:713-719.

Haber, W. 1990. Using landscape ecology in planning and management. Pages 217-232. In: I. Zonneveldt, and R. Forman (eds.). Changing Landscapes: An Ecological Perspective. Springer-Verlag. NY, USA.

Ilich, I. 1996. La sombra que arroja nuestro futuro. 
Páginas 69-85. In: N. Gardels (ed.). Fin de Siglo: Grandes pensadores Hacen Teflexiones Sobre Nuestro Tiempo. McGraw-Hill Interamericana, Spain.

Imhoff, D., and J. Baumgartner. 2006. Farming and the fate of wild nature. Watershed Media. Healdsburg, CA, USA. 264 p.

Jentoft, S. 2007. Limits of governability: Institutional implications for fisheries and coastal governance. Marine Policy 31:360-370.

Kassas, M. 1987. Seven paths to desertification. Desertification Control Bulletin 15:24-26.

Klijn, F., and H.A. Udo de Haes. 1994. A hierarchical approach to ecosystems and its implications for ecological land classification. Landscape Ecology 9:89-104.

Lawes, J. 1847. On agricultural chemistry. J. Roy. Agric. Soc. England. 8:226-260.

Lawrence, D. 1997. Integrating sustainability and environmental impact assessment. Environmental Management 21:23-42.

Lele, S. 1991. Sustainable development: a critical review. World Development 19:607-621.

Low, B., R. Costanza, E. Ostrom, J. Wilson, and C. Simon. 1999. Human ecosystems interaction: a dynamic integrated model. Ecological Economics 31:227-241.

Lubchenco J. 1998. Entering the Century of the Environment: A New Social Contract for Science. Science 279:491- 496.

Magel, H. 2000. Conference resume and presentation of the Potsdam Declaration Rural 21. Pages 63-77. In: Conference Volume Rural 21. International Conference on Future and Development of Rural Areas. EXPO 2000. Hanover, Germany.

Margalef, R. 1958. Information theory in ecology. General Systems 3:36-71.

Margalef, R. 1963. On certain unifying principles ecology. Am. Naturalist 97:357-374.

Margalef, R. 1969. Diversity and stability: a practical proposal and a model of interdependence. In: Diversity and stability in ecological systems. Brookhaven Symposia in Biology 22:25-37.

Martinez-Alier, J., and J. Roca. 2000. Economía Ecológica y Política Ambiental. PNUMA, Fondo de Cultura Económica. México. 493 pp.

Maturana H., and F. Varela. 1972. De Máquinas y Seres Vivos. Una teoría de la Organización Biológica. Editorial Universitaria. Santiago, Chile. $137 \mathrm{pp}$.

Maturana H., and F. Varela. 1992. The Tree of
Knowledge, the Biological Roots of Human Understanding. Shambala Publications. Boston, MA, USA. 269 pp.

Maturana H., and J. Mpodozis. 2000. The origin of species by means of natural drift. Rev. Chil. Hist, Nat. 73:261-310.

McDonnell, M., and S. Pickett (eds.). 1993. Humans as Components of Ecosystems: the Ecology of Subtle Effects and Populated Areas. SpringerVerlag. NY, USA. 364 p.

Meadows, D.H., D.I. Meadows, L. Randors, and W. Behrens. 1972. The Limits of Growth: A Report for the Club of Rome's Project in the Predicament of Mankind. Universe Books. NY, USA. $205 \mathrm{p}$.

Meeus, J., M. Winjermans, and M. Vroom. 1990. Agricultural landscape in Europe and their transformation. Landscape and Urban Planning 18:289352.

Mesarovic, M., and E. Pestel. 1975. La humanidad en la encrucijada. Segundo informe al Club de Roma. Fondo de Cultura Económica. México. $261 \mathrm{p}$

Mesarovic, M., M. Macko, and T. Takahara. 1971. Theory of hierarchical multilevel systems. Academic Press. NY, USA. 294 p.

Montalba, R. 2004. Historia de la transformación del sistema hombre en el medioambiente en el secano interior de la IX Región de Chile. Una Aproximación Agroecológica. Cuhuso 8:18-38.

Montalba, R. 2005. Agroecología como desarrollo rural sostenible en contextos indígenas, una aproximación crítica a partir de la realidad e historia de los mapuches de Chile. Tesis para optar al grado de Doctor en Agroecología y Desarrollo Rural Sostenible. Universidad de Córdoba. Córdoba. Spain. 450 pp.

Montalba, R., L. Vera, and C. Osorio. 2007. ¿Desarrollo sostenible o ecoetnocidio? Análisis agroecológico al proceso de expansión de monocultivos forestales desde la perspectiva de las poblaciones mapuche de Lumaco. In: Actas I Congreso de la Sociedad Científica Latinoamericana de Agroecología. Colombia. 141 pp.

Mott, G. 1960. Grazing pressure and the measurement of pasture production. pp. 606-611. In: Proceeding of the VIII International Grassland Congress. Reading. UK.

Naess, A. 1993a. Arne Naess. Pages 65-111. In: P. Reed and D. Rothenberg (eds.). Wisdom in the Open Air. University Minnesota Press. Minne- 
apolis, MN, USA.

Naess, A. 1993b. Sigmund Kvaløy. Pages 113-152. In: P. Reed, and D. Rothenberg (eds.). Wisdom in the Open Air. University Minnesota Press. Minneapolis, MN, USA.

Naredo, J. 2004. Diagnóstico sobre la sostenibilidad: La Especie Humana como Patología Terrestre. In: Archipiélago $\mathrm{N}^{\circ}$ 62. Jornadas sobre la sostenibilidad en el proyecto arquitectónico y urbanístico. Escuela Técnica Superior de Arquitectura de Madrid. Madrid, Spain. 12 pp.

Naveh, Z. 2000. What is holistic landscape ecology? A conceptual introduction. Landscape and Urban Planning 50:7-26.

Naveh, Z. 2001. Ten major premises for a holistic conception of multifunctional landscapes. Landscape and Urban Planning 57:269-284.

Nieswand, G., and P. Pizar. 1977. How to apply carrying capacity analysis. Pages 8-10. In: Environmental Comment. The Urban Land Institute. Washington DC., USA.

Nijkamp, P., C.J.M. Van den Bergh, and P. Soetman. 1990. Regional sustainable development and natural resource use. In: Proceedings World Bank Annual Conference and Development Economics. Washington DC., USA. p. 153-205.

Nisbet, R. 1982. Prejudices. A philosophical dictionary. Harvard University Press. Cambridge, MA, USA. 318 p.

Odum, E. 1953. Fundamentals of Ecology. W.B. Saunders, Philadelphia, USA. 384 pp.

Odum, E. 1969. The strategy of ecosystem development. Science 164:262-270.

Odum, E. 1975. Diversity as a functioning of energy flow. p. 11-14. In: W. Van Dobbar, and R. LoweMcConnell (eds.). Unifying Concepts in Ecology. Report of the Plenary Sessions of the First International Congress of Ecology. The Hague. Holland.

Ohrens, O., J. Alcalde y J. Gastó. 2007. Orkestike. Agronomía y Forestal UC 31:22-25.

ONU. 1972. Declaración de la Conferencia de las Naciones Unidas sobre el Medio Ambiente. Estocolmo. www.unep.org/Documents.Multilingual/Default.asp?DocumentID=97\&ArticleID= 1503. (Accessed: November, 2007)

ONU. 1977. Conferencia de las Naciones Unidas sobre la Desertificación. Asamblea general. Nairobi. www.un.org/documents/ga/res/32/ ares32r172.pdf (Accessed: December, 2007).

ONU. 1992. Declaración de Río sobre el Medio Ambiente y el Desarrollo. www.un.org/esa/sustdev/ documents/agenda21/spanish/riodeclaration.htm

(Accessed: October, 2007).

Pimentel, D., L. Hurd, A. Bellotti, I. Oka, O. Sholes, and R. Whitman. 1973. Food production and energy crisis. Science 182:443-449.

Plutchik, R. 2001. The nature of emotions. American Scientist 89:344-350.

Pontig, C. 1992. Historia Verde del Mundo. Ediciones Paidós Ibérica. Barcelona, Spain. 582 p.

Prigonine, I., and I. Stengar. 1984. Order out of chaos. Man's new dialogue with nature. Bantam Books. NY, USA. 349 p.

Queron, C. 2002. Relaciones entre actores sociales y territorio rural. El caso de la comuna de Santo Domingo. p. 717-751. In: J. Gastó, P. Rodrigo y I. Aránguiz. Ordenación Territorial, Desarrollo de Predios y Comunas Rurales. Facultad de Agronomía e Ingeniería Forestal, Pontificia Universidad Católica de Chile. Lom Ediciones. Santiago, Chile.

Redman, C.L., J.M. Grove, and L.H. Kuby. 2004. Integrating Social Science into the Long-Term Ecological Research (LTER) Network: Social Dimensions of Ecological Change and Ecological Dimensions of Social Change. Ecosystems 7:161-171.

Reichle, D., R. O’Neill, and W. Harris. 1975. Principles of energy and material exchange in ecosystems. p. 27-43. In: W. Van Dobben, and R. Lowe-McConnell (eds.). Unifying concepts in ecology. Report of the plenary sessions of the First International Congress of Ecology. The Hague, Holland.

Röling, N. 2000. Gateway to the global Garden: Beta/Gamma Science for Dealing with Ecological Rationality. Eight Annual Hopper Lecture. University of Guelph, Canada. $51 \mathrm{p}$.

Rosa, E. 2000. Modern theories of society and the environment: the risk society. p. 73-101. In: G. Spaargaren, A. Mol, and F. Buttel (eds.). Environment and global modernity. SAGE. International Sociological Association. SAGE Publication. London, UK.

Ruthenberg, H. 1980. Farming Systems in the Tropics. Clarendon Press. Oxford, UK. 366 p.

Scharnecchia, D. 1990. Concepts of carrying capacity and substitution ratios, a system viewpoint. Journal of Range Management 43:553-555.

Subercaseaux, D. 2007. Determinantes económicos en la ordenación territorial. Tesis Master of Science. Facultad de Agronomía e Ingeniería Forestal. Pontificia Universidad Católica de 
Chile. Santiago, Chile. 277 p.

Turner, T. 1973. Landscape planning: a linguistic and historical analysis of the term's use. Landscape and Planning. 9:179-192.

Van Mansvelt, J. 1997. An interdisciplinary approach to integrate a range of agro-landscape values as proposed by representatives of various disciplines. Agriculture, Ecosystems and Environment 63:233-250.

Vargas, G. 2005. Naturaleza y medio ambiente: una visión geográfica. Revista Geográfica Venezolana 46:289-304.

Vera, L. 2006. Origin and challenges of Cultural Landscape. From Labyrinth to the Global Garden. Essay Master of Science in Natural Resources Sciences. Universidad de La Frontera. Temuco, Chile. 31 pp.

Vial, J. 1981. El tiempo, cuestión de la filosofía. p. 31-53. In: J. Gómez (ed.). El tiempo en las Ciencias. Problemas Fundamentales del Hombre. Enfoque Interdisciplinario. Editorial Universitaria. Santiago, Chile.

Vitousek, P., H. Mooney, J. Lubchenco, and J. Melil- lo. 1997. Human domination on Earth's systems. Science 277:494-499.

Von Bertalanffy, L. 1975. Perspectives of general system Theory. Springer Verlag. NY, USA. 253 pp.

Wackernagel, W., and W. Rees. 2001. Nuestra huella ecológica, reduciendo el impacto humano sobre la tierra. LOM Ediciones. Santiago, Chile. 207 p.

Wilson, J. 1968. Increasing entropy of biological systems. Nature 219:534.

Winkelmann, D. 1993. La revolución verde: sus orígenes, repercusiones, críticas y evolución. Páginas 35-45. En: J. Cubero y M. Moreno (eds.). La Agricultura del Siglo XXI. Mundi-Prensa. Madrid, Spain.

Wu, J., and J. David. 2002. A spatially explicit hierarchical approach to modeling complex ecological systems: theory and applications. Ecological Modeling 153:7-26.

Wy, J., and Y. Qi. 2000. Dealing with scale in landscape analysis: an overview. Geographic Information Systems 6:1-5. 
